811.163.41'373.43

81'276.3-053.4

https://doi.org/10.18485/sj.2017.22.1.19

МАРИНА В. КЕБАРА*

Универзитет у Крагујевцу

Филолошко-уметнички факултет Крагујевац
Оригинални научни рад

Примљен: 19. 08. 2016.

Прихваћен: 15. 12. 2016.

\title{
СЕМАНТИЗАЦИЈА СПОНТАНИХ ДЕРИВАТА \\ (ДЕЧЈИХ НЕОЛОГИЗАМА) У ФУНКЦИЈИ ПРЕЦЕДЕНТНОСТИ ЈЕЗИЧКЕ ИГРЕ
}

Полифункционалност дечјих језичких творевина, као основни принцип њихове реторичке парадигме, представља темељни услов прецедентности, на основу којег је могуће класификовати типове семантичких поступака у деривацији неологизама као средства за грађење језичке игре (ЈИ). Циљ наше анализе у овом раду је: 1) класификација и опис поступака семантизације спонтаних деривата (неологизама/оказионализама $\mathrm{H} / \mathrm{O}$ ) уз истовремено издвајање и опис видова ЈИ као производа поменуте семантизације; 2) семантизација спонтаних деривата у функцији ЈИ као прецедента поетске употребе речи. Истраживање је обављено са лингвокогнитивног и психолингвистичког аспекта, с једне стране, и чисто лингвистичког с друге, на корпусу дечјег дискурса са српског и руског говорног подручја, у поређењу са уметничким (књижевним) дискурсом. Полазећи од структурних и структурно-семантичких параметара, као главног критеријума наше анализе и класификације, издвојили смо и описали два типа семантизације спонтаних деривата: 1) повезивање у ритмичке римоване низове лексички инкомпатибилних спонтаних деривата (Н/O), 2) римовано повезивање лексема у синтагматске низове паралелне по смислу или синтагматске опозиционе (антонимичне) низове. Наведени типови семантизације у подлози су три вида језичке игре: а) ритмизовани низови лексички инкомпатибилних $H / O$ по принципу сазвучја (фонетске складности), б) римовани синтагматски низови

*marina.kebara@gmail.com 
H/O паралелних по смислу в) римовани синтагматски низови Н/О по принципу контраст по смислу / аналогија по звучности.

Кључне речи: семантизација неологизама, полифункционалност дечје језичке игре, прецедентност, информативно-номинативна функција, атрактивна функција

\section{1. О ПОЛИФУНКЦИОНАЛНОСТИ ДЕЧЈЕ РЕТОРИЧКЕ ПАРАДИГМЕ КАО УСЛОВУ ПРЕЦЕДЕНТНОСТИ ЈЕЗИЧКЕ ИГРЕ ${ }^{1}$}

У лингвистици XX века доминирао је интерпретативни приступ, а њега данас све више замењује когнитивно-комуникативна парадигма знања, уграђена у основу психолингвистичких истраживања (Кубрјакова 1995, Слишкин 2004). Све уочљивија појава је заснивање научних приступа на антропоцентричности и широкој заступљености психолингвистичке анализе при разматрању мишљења, језика и говора у динамици њиховог међуделовања у комуникативном процесу. Овакав приступ захтева и нову методолошку позицију из које произилази системско динамичко поимање језичке свести, говора и комуникације, као и интегративно изучавање говорномисаоних механизама настајања исказа уопште и метајезичких исказа, као посебности, у форми језичке игре (ЈИ), а у процесу говорномисаоне делатности језичке личности. Појам и термин језичка личност (ЈЛ) у научни лексикон увео је руски лингвиста Ј. Н. Караулов (1987), иако се сматра да је његов прави аутор Г. И. Богин ${ }^{2}$. По одређењу Караулова, ЈЛ има троделну структуру: 1) вербално-семантички ниво (уобичајено, свакодневно владање природним језиком); 2) когнитивни ниво (слика света структурисана од појмова, идеја, концепата, као основних структурних јединица, што пружа могућност одражавања хијерархије вредности); 3) прагматични ниво (циљеви, мотиви, интересовања, усмереност, интенционалност, из чега настају услови за последични прелазак са вредновања говорне делатности ЈЛ на осмишљавање реалне делатности у објективном

\footnotetext{
${ }^{1}$ Проблемом прецедентности и полифункционалности дечјих творевина већ смо се бавили у нашим ранијим истраживањима (в. у: Кебара 2014: 109-125). У наведеном раду заступамо поставку да ,језичка игра, као посебан елемент игре уопште, по спољашњој форми представља чисто ритуалну, стандардну активност, али претходно осмишљену и изнутра организовану, засновану на одговарајућој замисли, тј. на концепцији поступка (чина) језичке личности, те се као таква темељи на њеној намери за постизање циља страног тој спољашњој активности; следи да је ЈИ динамична појава и по својој суштини процес, будући да је њено иманентно својство чин, деловање, који задржава унутар ње своју целовитост и стабилност.” (Кебара 2014: 112). У позадини наведене поставке налази се Бахтинов оксиморонски термин „реторика поступка” (Бахтин 2010), истовремено представљајући основу његове нове реторичке парадигме и теоријску подлогу нашег истраживања.

${ }^{2}$ Г. И. Богин је установио и представио појам ј е з ич ка л и чн о с т 1984. године у докторској дисертацији Модель языковой личности в ее отношении к разновидностям текстов (в. у списку литературе)
} 
свету). Говорномисаона делатност ЈЛ темељи се на рефлексивности речи као носиоца и ствараоца смисла и у директној је вези са усмереношћу, набојем и потенцијалом деловања мисли израженој у њој. Примена овог приступа омогућава поимање настајања мисли у речи (ретор[ичар], говорник) и речи у мисли (реторант), као и откривање унутрашње конфигурације речи путем анализе њеног (мета)смисаоног садржаја. Истраживање семантике речи у условима динамичности, смисаоне покретљивости и променљивости ствара основу за пребацивање феномена језичке игре у менталнорефлексивни простор и ниво посматрања, услед чега се ЈИ истражује у својству рефлексивне игре у функцији фундаменталне основе и принципа говорномисаоне делатности ЈЛ.

Остајући у оквирима когнитивне и психолингвистике, полазимо од поставке (Красних 1998, Прохоров 2004) да се знања и представе чувају у свести ЈЛ у когнитивним структурама (КС), које представљају својеврсну садржајну/смисаону форму кодирања и чувања информација (имају одређен садржај/значење). Информација, кодирана и чувана у виду КС, не садржи само податке у форми знања и представа о реалном свету, већ и знање језика и знање о језику, из чега следи разликовање феноменолошких и лингвистичких КС. Феноменолошке когнитивне структуре формирају тоталитет знања и представа о феноменима екстралингвистичке и чисто лингвистичке природе, док се лингвистичке когнитивне структуре налазе у основи језичке и говорне компетенције. У овом процесу значајно место има вербализација, будући да се не активизира само когнитивна структура-објекат, већ и когнитивне структуре-посредници, помоћу којих се и дешава вербализација, односно лингвистичке КС. Когнитивне структуре представљају својеврстан структурни материјал за прецедентне феномене (ПФ) и за когнитивну базу (КБ) и за у целини (свеукупност знања и представа којима владају сви представници одређеног лингво-културног друштва), чије језгро чине управо поменути ПФ. Прецедентни феномени, као основни елементи КБ, у својству су нуклеуса језичке свести која одражава и одређује специфична својства колективне језичке личности одређеног социјума, те као такви егзистирају у свести, језику, говору сваке појединачне ЈЛ. Истраживање и анализу у нашем раду заснивамо на међуделовању четири типа ПФ, иза којих истовремено стоји комплекс лингвистичких и феноменолошких структура и подељених у две групе: 1) вербални ПФ (прецедентно име ПИ и прецедентни исказ ПИС), 2) вербализовани ПФ (прецедентна ситуација ПС и прецедентни текст ПТ), од којих ћемо се посебно фокусирати на ПИ и ПИС. Прецедентно име је повезано са познатим текстом или ситуацијом, представљајући својеврстан сложен знак при чијој се употреби у комуникацији не врши ослањање на сопствени денотат, тј. референт, већ на скуп диференцијалних обележја датог ПИ, док се ПИС може одредити као завршени производ говорномисаоне делатности, сложен знак, збир значења који није једнак његовом смислу и као такав улази 
у КБ. Прецедентни исказ представља чисто лингвистички феномен „обавезно и редовно продукован у говору, за разлику од других ПФ који могу да буду потенцијално фреквентни" (Кебара 2014: 110). Са аспекта форме ПИС може да буде изражен или текстом-извором, или неком чисто језичком јединицом (синтагмом, реченицом, фразом), изграђеном по законима језика, али са добијеним статусом ПФ. Током анализе у раду за ПИС у значењу текста-извора употребаљавамо термин прототекст, текст-донор или денотат првог реда, на пример краћи дечји стихови, конкретно римовани синтагматски низови спонтаних деривата као производа дечје реторичке парадигме, изграђени по контрасту или по аналогији, а у функцији прецедента језичке игре у уметничком (књижевном) дискурсу.

Творба речи у дечјем говору карактерише се великим бројем неологизама, при чему дете-говорник врши сложене операције анализе и синтезе: најпре у процесу метајезичке рефлексије тумачи природу и именовање предмета, затим издваја у њему важна обележја, а потом их синтетизује и одређује им јединствено име на основу већ разрађених творбених (над)модела. Лингвокреативност представља суштинску (психо)лингвистичку специфичност дечје говорне делатности, која на нивоу речи може бити изражена у виду лексичко-семантичких иновација и преосмишљавања узуалне лексике, док се на нивоу текста испољава у виду језичке игре и/или наративне делатности. Полифункционалност дечјих творевина, као основни принцип њихове реторичке парадигме, представља темељни услов прецедентности, а циљ нашег рада је да полазећи од поменутог принципа: 1) класификујемо типове семантичких поступака у деривацији неологизама као средства за грађење језичке игре, уз истовремено издвајање и опис видова ЈИ као производа поменуте семантизације и потом да 2) поступке семантизације у функцији ЈИ одредимо и опишемо као прецеденте поетске употребе речи са аспекта (психо)лингвостилистике (психопоетике) и лингвокогнитивног функционалног приступа у упоредној анализи дечјег и уметничког дискурса. Усмереност ЈЛ на разумевање у процесу говорења увек претпоставља комуникативну тачност, под којом се подразумева остваривање комуникације у складу са очекиваним стандардом. Говорећи је константно усредсређен на координацију своје говорне делатности са перцепцијом адресата на кога је говор усмерен. Обично је овај процес скривен и одвија се на несвесном нивоу, међутим у одређеним моментима говорне делатности настаје својеврсно говорно напрезање, услед чега долази до одступања од стандарда, а даље се таква делатност вербализује у виду метајезичког коментара (Вепрева, 2005), прозвода метајезичке функције у језичкој свести ЈЛ. Постојање описаног метајезичког механизма ствара услове да се рутински комуникативни чин трансформише у креативни, када ЈЛ у процесу говорне делатности приступа естетском преосмишљавању свог свакодневног говорног искуства, стилски преобразујући на тај начин своју метајезичку информацију. 
У дечјим говорним творевинама грађење језичке игре најчешће се заснива на језичким антиномијама и аномалијама и у функцији је метајезичког исказа као иманентног принципа у говорној делатности ЈЛ, која производећи исказ кроз туђ говор (у овом случају у ЈИ) изражава тенденцију одступања од уобичајене, опште, колективне слике света. Описана делатност мотивисана је намерним, свесним одступањем од устаљене норме, са циљем изражавања сопствене позиције и личне слике света. У таквим условима и у складу са Бахтиновом новом реторичком парадигмом (Бахтин 1980, 2010), творац језичке игре може да се посматра као (мета)аутор-реторик, а ЈИ кроз позицију, односно говорнореторичку делатност свог творца оваплоћује реч и постаје исказ у дијалогичној функцији. У подлози полифункционалности дечје реторичке парадигме налазе се четири функције (Кебара 2014: 114): 1) информативно-номинативна функција (остварење стандарда на релацији норма/аномалија - неологизми, оказионализми и сличне творевине, које добијају статус ПФ, тачније ПИ и/или ПИС), 2) вредносно-оријентациона функција (оваплоћење експресије кроз чинове говорне агресије са изазивањем комичних ефеката - пошалице, ругалице исл.), 3) атрактивна функција (привлачење саговорникове пажње поступком антонимичне, контрадикторне замене познате речи, израза или знања у виду ПФ), 4) генерисање смисла (ефекат изневереног очекивања; постиже се реторичким поступком антонимичне трансформације, која је у супротности са уобичајеним начином мишљења - изокреталице, бесмислице и сл.). Током анализе у овом раду, са циљем решавања проблема прецедентности ЈИ као једног од постављених задатака, ослањамо се на параметре информативнономинативне функције (прецедентно име и прецедентни исказ), у корелацији са атрактивном функцијом (трансформисани прецедентни исказ). Поменуте функције у својству су базичних компоненти прецедентности издвојених, анализираних и описаних видова дечје ЈИ, функционално употребљених у значењу прототекста (текста-донора или денотата првог реда) у текстовима уметничког дискурса (текст-рецепијент или денотат другог реда).

\section{2. СТРУКТУРНИ И СТРУКТУРНО-СЕМАНТИЧКИ ПАРАМЕТРИ У ФУНКЦИЈИ СЕМАНТИЗАЦИЈЕ СПОНТАНИХ ДЕРИВАТА - РЕЗУЛТАТИ АНАЛИЗЕ}

Неологизми типа дечје етимологије, настали у процесу спонтане деривације, представљају плодну основу преосмишљавања и испуњавања текста новим смисловима, те се као такви често испољавају у својству прецедентних феномена у поетској употреби речи. Предмет нашег анализе предстваљају видови језичке игре (ЈИ) у дечјој реторичкој парадигми и дечјем дискурсу, формирани током процеса семантизације спонтаних деривата (неологизама/ 
оказионализама, даље у тексту Н/O), који предстваљају основу и главни услов структурног и структурно-семантичког прекодирања ПФ или прецедентног модела ЈИ у уметничком дискурсу. Корпус на којем смо разматрали проблем и изводили анализу чине дечји (индивидуално говорно-језичко стваралаштво деце са српског и руског говорног подручја) и уметнички дискурс, те смо у складу са тим примере ексцерпирали из: а) дечјих оригиналних изјава и творевина на руском језику, скупљених и забележених у књизи К. Чуковског Од друге до пете (у корпус смо уврстили како оригиналну књигу Чуковског на руском језику, доступну на веб-сајту, тако и превод ове књиге на српски језик у штампаном облику); б) дечјих оригиналних исказа и творевина деце са српског говорног подручја, скупљених и забележених у књигама наших аутора: Ј. Ј. Змаја Зелени миш и В. Рупник-Рачић, Б. Нешића Оловка пише сриее; в) антологија књижевности за децу, као и појединачних ауторских књига са уметничким текстовима за децу и одрасле у својству корпуса уметничког дискурса (в. у изворима на крају рада).

Структурни (форма) и структурно-семантички (форма и садржај/значење) параметри представљају два суштинска критеријума на којима се заснива анализа у овом раду и у подлози су поступака семантизације спонтаних деривата (Н/O), употребљених у функцији грађења језичке игре и то: 1) повезивањем насталих деривата у ритмичке римоване низове лексички инкомпатибилних Н/O (структурни параметри), 2) римованим повезивањем у синтагматске опозиционе (антонимичне) низове или низове лексема паралелних по смислу (структурно-семантички параметри). Прва група параметара (структурни) у подлози је оказионалне деривације као средству за грађење ЈИ засноване на сазвучју (фонетској складности), при чему се семантизација врши искључиво ритмизованим римовањем неологизама чије се лексичко значење губи или је занемарено, док је друга група (структурно-семантички параметри) у подлози семантизације спонтаних деривата као поступка за грађење два типа језичке игре: а) римовано повезивање Н/О паралелних по смислу, б) римовано повезивање Н/О по принципу контраст по смислу / аналогија по звучности (сазвучје).

\section{1. Структурни параметри у функцији семантизације спонтаних деривата}

У ову категорију сврставамо оказионалну деривацију као средство за грађење ЈИ засноване на семантизацији деривата путем гласовног сазвучја (фонетске складности) без посебне усмерености на постизања лексичке компатибилности, што имплицира одсуство лексичког значења. У поменутом поступку присутна је тенденција ка ритмичности и рими у дечјој реторичкој парадигми, уз примарност форме у односу на садражај (значење). 
2.1.1. ЈИ као поступак семантизације римовањем лексички инкомпатибилних H/O. - Овај тип језичке игре заснива се на римовању бесмислених речи, при чему су или све лексеме у синтагматском низу бесмислене, или пак само један елемент низа (са искључивањем аналогије или контраста, дакле и било какве систематизације речи, што је присутно у оба ниже описана типа ЈИ, в. параграфе 2.2.1. и 2.2.2.). Поступак семантизације у поменутом типу ЈИ искључиво је у функцији остваривања експресије и комичног ефекта у игровној комуникацији и у основи је римованих и ритмизованих синтагми дечје ЈИ, која од говорне функције изражавања у игровној комуникацији (примери 1 и 1a) може да се преобрази у реторички поступак грађења целовитих текстова у дечјем дискурсу (пример 1б; 1д, 1ђ, 1е):

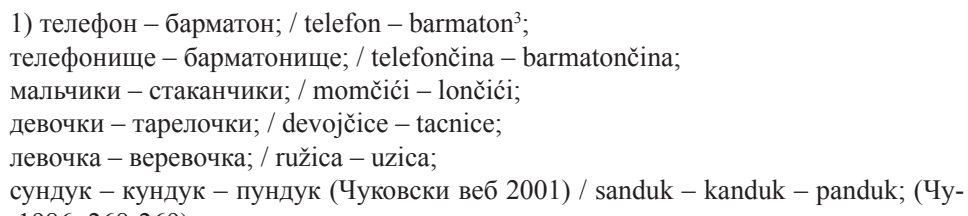

1a) Трехлетняя Галя говорит своей матери: / Trogodišnja Galja kaže, na primer, svojoj majci:

- Мама, скажи: Галюнчик. Мама говорит: - Галюнчик. Галя рифмует:- Мамунчик. / - Mama kaži: Galunčik. Mama kaže: - Galunčik. Galja rimuje: - Mamunčik.

Тогда мать говорит: - алюха. А Галя: - Мамуха. / Onda mama kaže: - Galuha. A Galja: - Mamuha.

Мать: - Галушка. А Галя: - Мамушка. / Majka: - Galuška. A Galja: - Mamuška.

Мать: - Галубуха. Галя: - Мамумуха. (Чуковски веб 2001) / Majka: - Galubuha Galja: - Mamuluha. (Чуковски 1986: 268)

Иманентни принцип описаног типа језичке игре је успостављање сазвучја (фонетске складности) у сврху постизања ритма и риме, уз истовремено губљење/занемаривање смисла стихова. На тај начин, омогућено је грађење текстова са ритмизованим римама организованим искључиво од бесмислених, лексички инкомпатибилних лексема, али структурно смислених, односно ритмички семантизованих, што је једна од најзаступљенијих језичких игара у дечјој реторичкој парадигми:

1б) Это разве ложка? / Zar je ovo kašičica

Это просто кошка. / To je prosto stoličica.

Это разве печка? / Zar je ovo pećica?

Это просто свечка... (Чуковски веб 2001) / To je prosto svećica... (Чуковски 1986: 270)

${ }^{3}$ Превод дечјих творевина из књиге Чуковског Od druge do pete (Чуковски 1986) припада Љубинки Крешић, преводиоцу наведене књиге. 
(1в) Кунда, мунда, карамунда, / Kunda, munda, karamunda, 1986: 272)

Дунда, бунда, парамун. (Чуковски веб 2001) / Dunda, bunda, paramun. (Чуковски

(1г)Индияндаa, Индиянда, Индия! / Indijanda

Индияди, Индияди, Индия! (Чуковски веб 2001) / Indijadi, Indijadi, Indija! (Чуковски 1986: 279)

(1д) Эндепдине, бететон. / Endepdine, beteton!

Эндендине, бететон! / Endendine, beteton!

Горбонове реткос! / Gorbonove retkos!

Горбонове реткос! (исто) / Gorbonove retkos! (исто)

Структурни поступак семантизације грађењем ритма у напред наведеним примерима заснива на гласовним варијацијама прве речи у понављањима, са циљем постизања динамичности и догађајности уз истицање појачане експресије и активности учеснка језичке игре, што се још јасније уочава у следећим самосталним творевинама деце-аутора:

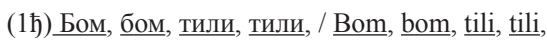

Нашу маму сократили. / Našu mamu otpustili.

Бом, бом, тили, тили, / Bom, bom, tili, tili,

Нашу маму сократили. (Чуковски веб 2001)/ Našu mamu otpustili. (Чуковски 1986: 290)

(1e)_римпампопи! / Drimpapon!

Римпампони! / Rimpapon!

Едет папа на вагоне, / Seo tata u vagon -

Молодец паровоз - / Mašina k'o strela

Хорошо его довез! (Чуковски веб 2001)/ Kući ga donela! (Чуковски 1986: 291)

У анализираним примерима, текстови засновани на описаној ЈИ и заступљени у дечјем дискурсу остварују функцију текстова-донора или денотата првог реда, те тако и прецедента за текстове у уметничком (књижевном) дискурсу, које можемо означити као текстове-рецепијенте или денотате другог реда, са истим типом семантизације и ЈИ у поетском поступку:

(1ж) Тарам-барам-беца / - Шта је тарам? / Тарам је тарам, / барам је барам, / беца је беца, /- тако се варају мала деца! (Д. Радовић у: Антологија 1995: 187)

(13) Бимбури, / бамбури, / бум - / кокица стала на друм! / (...) / Ту прође репата

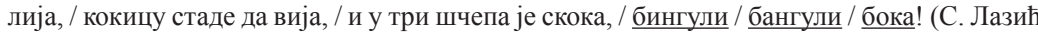
у: Антологија 1995: 188)

(1и) Ој, дуледу, дуледу, / Овако је на леду. / Ноге као стреле, / Терај, брацо, селе! [...] (Ј. Ј. Змај у: Антологија 2007: 32)

(1ј) Мејо, мејане, / Голубане, белане, / Примакниде главицу, / Па окуси травицу! [...] (Ј. Ј. Змај у: Антологија 2007: 8)

(1к) Dolomani, hitar, hitar, / Pohurimo Istar, Istar! / A udarci panovski / Dolaze nam ponovski. (Николај Асејев у: Антологија 1975: 213) 


\section{2. Структурно-семантички параметри у функцији семантизације спонтаних деривата}

Иманентну законитост дечје реторичке парадигме представља унутрашња перцепција творевина у форми звучне игре путем сазвучја, односно фонетске складности (на шта је указано у претходном параграфу), а осим структурног кодирања, заступљено је и структурно-семантичко. Сходно реченом, многе речи у дечјој језичкој свести живе у паровима, који најчешће представља њену антитезу, док се њихово синтагматско повезивање врши по аналогији или по контрасту. Полазећи од наведених својстава дечјег говора, при чему је фокус на грађењу риме и ритма као критеријуму типологије, извели смо следећу класификацију језичких игара, са поменутим поступком семантизације у основи: 2) ЈИ као поступак семантизације римовањем $\mathrm{H} / \mathrm{O}$ паралелних по смислу, 2) ЈИ као поступак семантизације римовањем Н/O на релацији контраст по смислу/аналогија по звучности (сазвучје).

2.2.1. ЈИ као поступак семантизације римовањем Н/O паралелних по cмислу. -Ток семантизације у поменутом поступку одвија се путем разјашњавања унутрашње форме речи доградњом недостајућих веза у узуалном систему номинације у сврху постизања језичке симетрије (најчешће формалном аналогијом и чисто језичким механизмима) и/или по принципу семантичког укључивања, уколико се у творбеним структурама одражавају различите когниције (вербализација, вербални ПФ $\rightarrow$ ПИ; упор. у примеру 2б). На тај начин, успоставља се „структурна аналогија (случајна/намерна фонетска/морфолошка сличност) са већ усвојеним узусним лексемама" (Кебара 2016: 315), дајући за производ спонтане деривате који образују номинативне низове паралелне узусу. Описани поступак семантизације неологизама/оказонализама представља суштински динамички принцип информативно-номинативне функиије дечје говорне/реторичке парадигме, која се може одредити као „прецизирање или разјашњавање унутрашње форме речи путем њихове делимичне формалне модификације или корелације са разумљивим мотиватором" (Кебара 2014: $115)$ и са израженим принципом метајезичке рефлексије, чији је резултат „когнитивна прерада рефлектованих језичких алгоритама: одступање од конкретног творбеног (деривационог) модела ради успостављања језичке симетрије" (Кебара 2014: 116):

(2) - Жил-был пастух, его звали Макар. И была у него дочь Макарона. (Чуковски веб 2001) / - Bio jedan pastir, zvao se Makar [мотиватор, нап. М.К]. I imao je kćerku Makaronu. (Чуковски 1986: 27)

(2a) - Мне сам папа сказал... / - Meni je lično [мотиватор, нап. М.К] tata kazao...

- Мне сама мама сказала... / - Meni je lično mama kazala...

- Но ведь папа самее мамы... Папа гораздо самее. (Чуковски веб 2001) / - Ali tata je ličniii od mame... Tata je mnogo ličniji. (Чуковски 1986: 25) 
(2б) - Как ты смеешь драться? [мотиватор, нап. М.К] / - Kako smeš da se tučeš

- Ах, мамочка, что же мне делать, если драка так и лезет из меня! (Чуковски веб 2001) / - Pa, šta da radim mamice, kad tuča [лексема са добијеним статусом ПФ, тачније ПИ, нап. М. К.] sama izlazi iz mene? (Чуковски 1986: 27)

Поменута функција и поступак семантизације темељни су принципи језичке игре у дечјем дискурсу са структурно-семантичким параматрима у подлози - римовано спајање речи паралелних по смислу. У ниже наведеним примерима (2в), (2г) узусне лексеме у функцији мотиватора за грађење спонтаних деривата по принципу формалне аналогије истакли смо подвлачењем, док су од њих настали дечји неологизми у ванузусној употреби подвучени и болдирани ( *испред њих означава нестандардну форму, односно одступање од језичке норме); у примерима (2д), (2ђ) формирани су римовани синтагматски низови од Н/О као њихових структурних елемената, при чему су подвучене неболдиране лексеме такође мотиватор за други елемент (болдирана подвучена лексема) синтагматског низа, у функцији целовите језичке јединице:

(2в) - Няня его * нянчила, мама его *мамчила. (Чуковски веб 2001) / - Dadilja ga je * dadiljala, mama ga je * mamiljala. (Чуковски 1986: 266)

(2г) И вот что сказала Ляля, когда какая-то девочка в купальне похитила мамины туфли: / A evo šta je rekla Ljalja kad je neka devojčica ukrala mamine cipele iz kabine na kupalištu:

- Она их * примерякала [од узусног примерять/пробати као мотиватора, нап. М.К] и * присебякала [од узусног присвоить, присвоить для себя// присвојити, приписати себи, као мотиватора, нап. М.К]. (исто) - Ona ih je *isprobatala $\mathrm{i}$ *prisvojatala. (исто)

(2д) молик - полик / molić - polić

стульчик - мульчик / stoličica-moličica

Bacя - Tapacg / Vasja - Tarasja

бабушка - колабушка / bakica - makica

дятел - долбятел (Чуковски веб 2001) / detlić - dubetlić (Чуковски 1986: 266)

(Упор. овај тип дечје језичке игре са игром речи у устаљеним синтагмама у српском језику: тандара-мандара, шиге-миге, хокус-покус, малчић-палчић исл.)

(2ђ) - Папа, а будут сегодня передавать по телевизору мульти - пульти? (исто) / Tata, a hoće li danas biti na televiziji multi - pulti? ${ }^{4}$ (исто)

Дечја реторичка парадигма са аспекта функционалности представља дискурс у којем се „наизменично смењују лични динамични системи форми и значења, изграђени у процесу акумулације (нагомилавања) говорног искуства и разумевања језика" (Кебара 2014: 116). Наведени примери одраз су дечје лингвокреативности која је на нивоу речи изражена у виду лексичко-семантичких иновација и преосмишљавања узусне лексике (2в, 2г), док је на нивоу текста испољена у виду језичке игре са прецедентним именом као вербалним ПФ у подлози (2д, 2ђ). Поменути ПФ постоји у когнитивној бази у својству утврђене

${ }^{4}$ мультипликация // мултипликација (цртани филм) 
структуре, услед чега је могуће играње формом и значењем. Дечје говорне творевине са информативно-номинативном функцијом у основи препознају се као прецедент (вербални ПФ - ПИ, ПИС) поетске употребе речи, па сходно и текст-донор у функцији денотата првог реда за уметнички текст-рецепијент или денотат другог реда:

(2е) Ћири ба - ћири бу! / Мене нема, ти си ту. / Ћири бу - ћири ба! / Тебе нема, ту сам ја. / Хокус покус препарандус / Увек неко нестадандус. / (...) / Хокус покус препарандус /Час постандус, час нестандус. (Ђуро Милекић у: Антологија 2000: 90)

(2ж) Vremari-ševari / Na jezera obali, / Gde je kamen vreme, / Gde je vreme kamen. / Na obale jezeru/ Vremari-ševari... (В. Хлебњиков у: Антологија 1975: 124)

(23) U zavaracima-sanovnjacima / Odmorio sam se kraj crte. / U maštenjacimamišljenjacima / Kraj mašte se vrteh. (исто)

(2и) Живела су чет’ри брата: / Тика, Жика, Сава, Вава, / Па имали воденицу, /

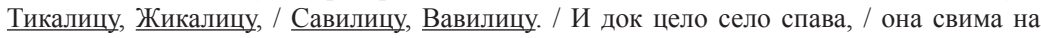
весеље, / тика, жика, жика, тика, / сава, вава, вава, сава. (Гордана Брајовић у: Антологија 2007: 15)

2.2.2. ЈИ као поступак семантизације римовањем Н/O на релацији контраст по смислу/аналогија по звучности (сазвучје). - Семантизација неологизама у дечјој реторичкој парадигми грађењем антонимичних опозиција поступком спајања и римовања речи супротних по значењу корелативна је са поступком спајања лексема паралелних по смислу, будући да је коначни циљ оба типа семантизације постизање језичке симетрије и попуњавање лексичких лакуна. Овај тип ЈИ гради се семантичким поступком комутаиије (пребачивања) мотивачионог кода (Кебара 2016: 318), заснованом на довођењу неологизама-антонима у антонимичну позицију у односу на узусне речи, при чему се именују реалије и/или ситуације које не постоје у објективном свету, а прототип се освешћава кроз игровну трансформацију (трансформисани прецедентни исказ ТПИС). Примере лексема које означавају стварну позицију реалија (унутарузусна употреба) истакли смо подвлачењем, док су лексеме са израженим оступањем од ње (ванузусна употреба Н/O) подвучене и болдиране:

(3) - Светик, нельзя кушать лёжа./ - Iljuša, ne treba jesti ležeći.

- Хорошо, я буду кушать сёжа. (Чуковски веб 2001)/ - Dobro, onda ću jesti sežeći. (Чуковски 1986: 264-265)

(антонимична римована опозиција: лёжа $/ *$ сёжа //

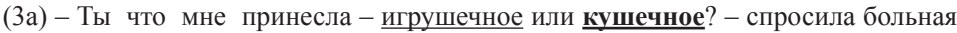
четырехлетняя девочка, когда мать явилась к ней в больницу с подарками. (исто)/ - Šta si mi donela: igračku ili jedačku? - pitala je bolesna četvorogodišnja devojčica kad je majka došla u bolnicu s poklonima. (исто)

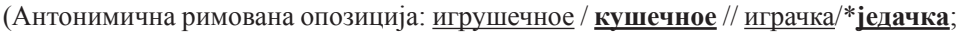
упор. са игром речи у српском језику: играчка-плачка).

${ }^{5}$ Деривационе лексеме (Н/O), које својом формом одступају од стандарда или не припадају узусу, означили смо *испред (њих). 
(3б) - Ты будешь покупатель, а я продаватель./ - Ti ćeš biti kupac, a ja prodac.

- Не продаватель, а продавец./ - Ne prodac, već prodavac.

- Ну хорошо: я буду продавец, а ты покупещ. (исто) /- Pa dobro, ja ću biti prodavac, a ti kupavac. (Чуковски 1986: 264-265)

(Антонимичне римоване опозиције: покупатель / купещ // купац/* продац и продавац/*купаващ).

(Зв) Правда је друго а кривда је друго. (Рупник-Рачић, Нешић 1982: 130)

(Антонимична римована опозиција: правда /*кривда).

(3г) Кад неко нема имаштину то се зове немаштина, тај плаче ко има немаштину. (Рупник-Рачић, Нешић 1982: 92)

(Антонимична римована опозиција: немаштина /* имаштина и прецедентно име

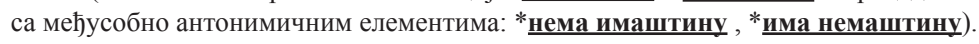

(3д) Гласан је јако дерање

Тих је полако дерање. (Рупник-Рачић, Нешић 1982: 44)

(Антонимијска опозиција на нивоу синтагме са статусом ПФ: јако *дерање / * по-

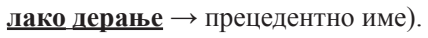

Процес семантизације у наведеним примерима ЈИ заснива се на грађењу антонимијских опозиција и употреби антонимичних лексема, најчешће римованих, или синтагми са структурним елементима у међусобно антонимичном односу (без постизања риме), са интенцијом усмереног (свесног) моделирања језичког парадокса. Метајезичком рефлексијом, као динамичким принципом поменутог процеса семантизације, расветљава се унутрашња форма речи, чиме се сагледава стварна позиција реалија из објективног света, опонирана у насталим спонтаним дериватима. Антонимична употреба речи и/или синтагми у функцији је стварања комичног ефекта ЈИ, наглашавањем експресије именованог опонента, чиме се добијају вербални ПФ, тачније трансформисани прецедентни искази (ТПИС) са контрастом у подлози:

(3ђ) Мати: Иди, сине, купи ми један лимун у дућану, али бирај који нема дебелу кору. Син (у дућану): Дајте ми један лимун, али који има мршаву кору. (Змај 1982: 37)

(3е) Знао сам да је оџачар у кући, од кога Даница као да малко зазире. Запитам је: - А ди је сад оџачар?

- Доле.

- Ди доле?

- На тавану.

- Па зар је то доле?

- Е, он је био горе, чак на оџаку, па сад је сишао доле на таван. (Змај 1982: 20)

Оперативна снага ТПИС, као симбола прецедентног феномена и прототекста, условљена је ефектом изневереног очекивања. Поступком антонимичне замене по принципу теза-антитеза, на којем се темељи атрактивна функција (Кебара 2014) ${ }^{6}$, граде се нове стилске нијансе необичношћу коришћења

${ }^{6}$ Атрактивна функција управо се базира на привлачењу саговорникове пажње поступком ,антонимичне замене познатих речи, израза (вербални ПФ) или знања (вербализовани ПФ 
познатих речи, израза или знања (ПФ). Језичке творевине дечјег дискурса са поменутом говорном/реторичком функцијом у основи постају прецедент (текст-донор), односно денотат првог реда за уметнички текст, који се са овог аспекта може посматрати као денотат другог реда (текст-рецепијент), што имплицира да ЈИ дечје реторичке парадигме врши функцију прецедента за поетску употребу речи, преображавајући се у реторички поступак у уметничком дискурсу:

(3ж) Мајка чеду тепа:/ „Слатки, мали сине”,/ А он има девет/ Метара дужине. // Још му она тепа:/ „Бебо моја мила”,/ А та беба има/ Две хиљаде кила. (Г. Тартаља у: Антологија 2007: 8-9)

(33) Mala djeca ne poznaju dobro riječi/ i ne razlikuju što znači „,kotao" a što „,ćup”/ i ne razlikuju što znači „,oštar” a što „tup”/ pa će tako poneko od njih reći:/ Ti o svemu sve znaš, tata! Tako si glup! (Д. Хорватић у: Антологија 1984: 37)

(Зи) Шта ће с тобом бити, ко зна/ Лепотище моја грозна?/ Бићеш личност негативна,/ ругобице моја дивна! (Љ. Ршумовић у: Антологија 2007: 13-14)

(3j) Bejah vera ti nevera/ ja nevera ti si vera (...)/ ja siromah a ti bogat/ siromah sam al' bogato/ ti si bogat ali tanko ... (Л. Гал у: Антологија 1984: 170)

У атрактивној функцији степен свесности, у односу на информативнономинативну функцију већи је, те у њој свест језичке личности „као организован материјални израз” (Бахтин 1980: 100) поседује снажну „делотворност” (Бахтин 1980: 100). Основна тежња ЈЛ у овом типу језичке игре усмерена је на „активну перцепцију и реакцију у говорној интеракцији” (Кебара 2014: 120), на чему се управо и заснива дијалогичност поменуте ЈИ.

\section{3. ЗАКЉУЧАК}

Са аспекта функционалности, дечја реторичка парадигма представља дискурс у којем се наизменично смењују лични динамични системи форми и значења, из чега произилазе два основна својства дечје говорне делатности: лингвокреативност и полифункционалност. Лингвокреативност је на нивоу речи изражена у виду лексичко-семантичких иновација и преосмишљавања узусне лексике, док је на нивоу текста испољено у виду језичке игре са прецедентним именом и прецедентним исказом, као вербалним ПФ у подлози. Полифункционалност дечјих творевина, са значењем основног принципа њихове реторичке парадигме, представља темељни услов прецедентности, а полазећи од његовог тумачења и описа, остварили смо два постављена задатка у раду: 1) класификација и опис типова поступака семантизације спонтаних деривата $(\mathrm{H} / \mathrm{O})$ као средства за грађење језичке игре, 2) њихово одређење и опис као прецедената поетске употребе речи са аспекта (психо)лингвостилистике

- прецедентни текст), међусобно повезаних или по аналогији или по контрасту” (Кебара 2014: 119) 
(психопоетике) и лингвокогнитивног функционалног приступа у упоредној анализи дечјег и уметничког дискурса. У подлози полифункционалности дечје реторичке парадигме налазе се четири функције, а током анализе у раду ослањали смо се на параметре информативно-номинативне функције (остварење стандарда на релацији норма/аномалија - Н/О, који добијају статус ПФ, тачније прецедентног имена и/или прецедентног исказа) и атрактивне функције (привлачење саговорникове пажње поступком антонимичне, контрадикторне замене познате речи, израза или знања у виду ПФ тачније, трансформисаног прецедентног исказа). Ове две функције представљају темељне компоненте прецедентности издвојених, анализираних и описаних видова дечје ЈИ, а употребљених у својству прототекста (текста-донора или денотата првог реда) у текстовима уметничког дискурса (текст-рецепијент или денотат другог реда).

На основу две групе параметара, као главног критеријума анализе: а) структурни (форма) и б) структурно-семантички (форма и садржај/значење), издвојили смо и описали два типа поступака семантизације спонтаних деривата (H/O), употребљених у функцији грађења језичке игре: 1) повезивање насталих деривата у ритмичке римоване низове лексички инкомпатибилних H/O (структурни параметри), 2) римовано повезивање лексема у синтагматске низове паралелне по смислу или синтагматске опозиционе (антонимичне) низове (структурно-семантички параметри). Описани поступци, и са њима корелативни видови ЈИ, уочени су у дечјем дискурсу оба анализирана језика (руски/српски). Наведени типови семантизације у подлози су три вида дечје језичке игре:

1. ЈИ као поступак семантизаиије римовањем лексички инкомпатибилних $H / O$ : римовање бесмислених речи, при чему су или све лексеме у синтагматском низу бесмислене, или пак само један елемент низа са циљем остваривања експресије и комичног ефекта у игровној комуникацији (примери: 1, 1a, 1б, 1в, 1г, 1д, 1ђ, 1е). Поменута ЈИ уочена је као прецедент у текстовима уметничког дискурса (примери: 1ж, 1з, 1и, 1j, 1к).

2. ЈИкао поступак семантизаиије римовањем Н/О паралелних по смис$л y$ : разјашњавање унутрашње форме речи доградњом недостајућих веза у узуалном систему номинације у сврху постизања језичке симетрије (најчешће формалном аналогијом и чисто језичким механизмима) и/или по принципу семантичког укључивања, уколико се у творбеним структурама одражавају различите когниције (вербализација, вербални ПФ $\rightarrow$ ПИ; примери: 2, 2а, 2б, 2в, 2г, 2д, 2ђ). Описани поступак семантизације у подлози је информативно-номинативне функиије дечје говорне/реторичке парадигме и као такав представља 
Кебара М., Семантизација спонтаних деривата...; Српски језик XXII, 2017, стр. 315-331 329

прецедент за текстове уметничког дискурса (примери: 2е, 2ж, 23, 2и).

3. ЈИ као поступак семантизације римовањем Н/О на релацији контраст по смислу/аналогија по звучности (сазвучје): грађење антонимичних опозиција спајањем и римовањем речи супротних по значењу а анологних по звучности (фонетска складност) семантичким поступком комутације (пребацивања) мотивационог кода, при чему се именују реалије које не постоје у објективном свету, а прототип се освешћава кроз игровну трансформацију $\rightarrow$ трансформисани прецедентни исказ ТПИС, као симбол прецедентног феномена и прототекста (примери: 3, 3а, 3б, 3в, 3г, 3д, 3ћ, 3е). Овај вид дечје ЈИ у подлози је атрактивне функиије и као такав добија статус прецедентног текста-донора (денотат првог реда) за уметнички текстреципијент, односно денотат другог реда у уметничком дискурсу (примери: $3 ж, 33,3$ и, 3j).

\section{ИЗВОРИ}

Антологија 1975: Moderna ruska poezija, priredile N. Bogdanović, M. Nikolić, Beograd: NOLIT.

Антологија 1984: Milovan Vitezović, Radomir Smiljanić, Antologija savremene jugoslovenske poezije za decu, knj. 1, Beograd: ILF, ZAPIS, preuzeto izdanje Aranđelovac: NAPREDAK.

Антологија 1995: Антологија српске књижевности за дещу I, поезија, приредио Д. Јекнић, Београд: Мак.

Антологија 2000: Избор из поезије за дјещу пјесника из Републике Српске, приредио Др Цвијетин Ристановић, Српско Сарајево: Завод за уџбенике и наставна средства.

Антологија 2007: Од Змаја до Љубивоја, ризница српске поезије за деиу, уредио Н. Кебара, Крагујевац: Лира.

Змај 1982: Ј. Ј. Змај, Зелени миш, досеткке и наивности из дечјег света, изабрао и приредио М. Витезовић, Ваљево: Милић Ракић.

Змај 2007: Јован Јовановић Змај, Ризница: песме за деиу и о деци, уредио Н. Кебара, Крагујевац: Лира.

Рупник-Рачић, Нешић 1982: V. Rupnik-Račić, B. Nešić, Olovka piše srcem, Beograd, DELTA PRESS. 
Чуковски 1986: Kornej Čukovski, Od druge do pete, Beograd: Zavod za udžbenike i nastavna sredstva.

Чуковски веб 2001: ИС: Корней Чуковский, Собрание сочинений в 15т. Т. 2: Од двух до пяти, Москва: Терра-Книжный клуб, 2001, доступно на http://www.chukfamily.ru/Kornei/Prosa/Ot2do5/Ot2do5.htm

\section{ЛИТЕРАТУРА}

Бахтин 1980: Mihail Bahtin, Marksizam i filozofija jezika, Beograd: Nolit.

Бахтин 2010: Mihail Bahtin, Ka filosofiji postupka, Beograd: Službeni glasnik.

Богин 1984: Богин Г. И. Модель языковой личности в ее отношении к разновидностям текстов: Автореф. дис. ... докт. филол. наук. - Л., 1984, доступно на http://www.dissercat.com/content/ russkaya-yazykovaya-lichnost-v-aspekte-lingvokognitivnykh-stileireprodutsirovaniya-nauchnog.

Караулов 1987: Ю . Н. Караулов, Русский язык и языковая личность, Москва: Наука.

Вепрева 2005: И. Т. Вепрева, Языковая рефлексия в постсоветскую эпоху, Москва: ОЛМА-ПРЕСС.

Кебара 2014: Марина Кебара, Језичка игра у дечјем дискурсу као прецедент поетске употребе речи, Кюижевност за деиу у науци и настави, зборник радова, књ. 18, Универзитет у Крагујевцу, Педагошки факултет Јагодина, 109-125.

Кебара 2016: Марина Кебара, Лингвокогнитивна функционална анализа дечјих неологизам као метајезичких рефлексива у језичкој игри, Београд: Српски језик XXI, Београд, 311-324.

Красних 1998: В. В. Красных, Виртуальная реальность или реальная виртуальность (Человек. Сознание. Коммуникация), Москва: Диалог-МГУ.

Кубрјакова 1995: Е. С. Кубрякова, Эволюция лингвистических идей во второй половине XX века (опыт парадигмального анализа), Язык и наука кония 20 века, Москва: Институт языкознания РАН, 144-238.

Прохоров 2004: Ю.Е. Прохоров, Действительность. Текст. Дискурс, Москва: Флинта: Наука.

Слишкин 2004: Г. Г. Слышкин, Лингвокультурные конщепты и метаконцепты : монография, Волгоград : Перемена. 
Кебара М., Семантизација спонтаних деривата...; Српски језик XXII, 2017, стр. 315-331 331

\section{СЕМАНТИЗАЦИЯ СПОНТАННЫХ ДЕРИВАТОВ (ДЕТСКИХ НЕОЛОГИЗМОВ) В ФУНКЦИИ ПРЕЦЕДЕНТНОСТИ ЯЗЫКОВОЙ ИГРЫ}

\section{Резюме}

Полифункциональность детских языковых творчеств, в качестве основного принципа их риторической парадигмы, представляет собой фундаментальное условие прецедентности, на основании которого можно классифицировать типы семантических приемов в деривации неологизмов как средства для построения языковой игры (ЯИ). В этой статье мы решаем две основные задачи: 1) классификация и описание приемов семантизации спонтанных дериватов (неологизмов/окказионализмов Н/O), с одновременным выделением и описанием видов ЯИ в качестве продукта упомянутой семантизации; 2) семантизация спонтанных дериватов в функции ЯИ, как прецедента поэтического использования слова. Исследование проводилось с учетом психолингвистических и лингвокогнитивных аспектов, с одной стороны, а с другой собственно лингвистических, на корпусе детского дискурса (в сербском и русском языках) по сравнению с художественным (литературным) дискурсом. Исходя из структурных и структурно-семантических параметров, в качестве основного критерия нашего анализа, мы выделили и описали два типа семантизации спонтаных дериватов: 1) связывание в ритмические рифмованные ряды лексически несовместимых спонтаных дериватов (Н/O), 2) рифмованное связывание лексем в синтагматические ряды параллельные по смыслу или синтагматические оппозиционные (антонимичные) ряды. Данные типы семантизации лежат в основе трех видов языковых игр: а) ритмизованные ряды лексически несовместимых $H / O$ согласно принципу созвучия (фонетической согласованности), б) рифмованные синтагматические ряды $\mathrm{H} / \mathrm{O} \mathrm{na}$ раллельные по смыслу, в) рифмованные синтагматические ряды $H / O$ согласно принципу контраст по смыслу/аналогия по звучании (звуку).

Ключевые слова: семантизация неологизмов, полифункциональность детской языковой игры, прецедентность, информативно-номинативная функция, аттрактивная функция.

Марина В. Кебара 